H. BURGE $E T A L .:$ SELECTIVE VAGOTOMY WITHOUT DRAINAGE

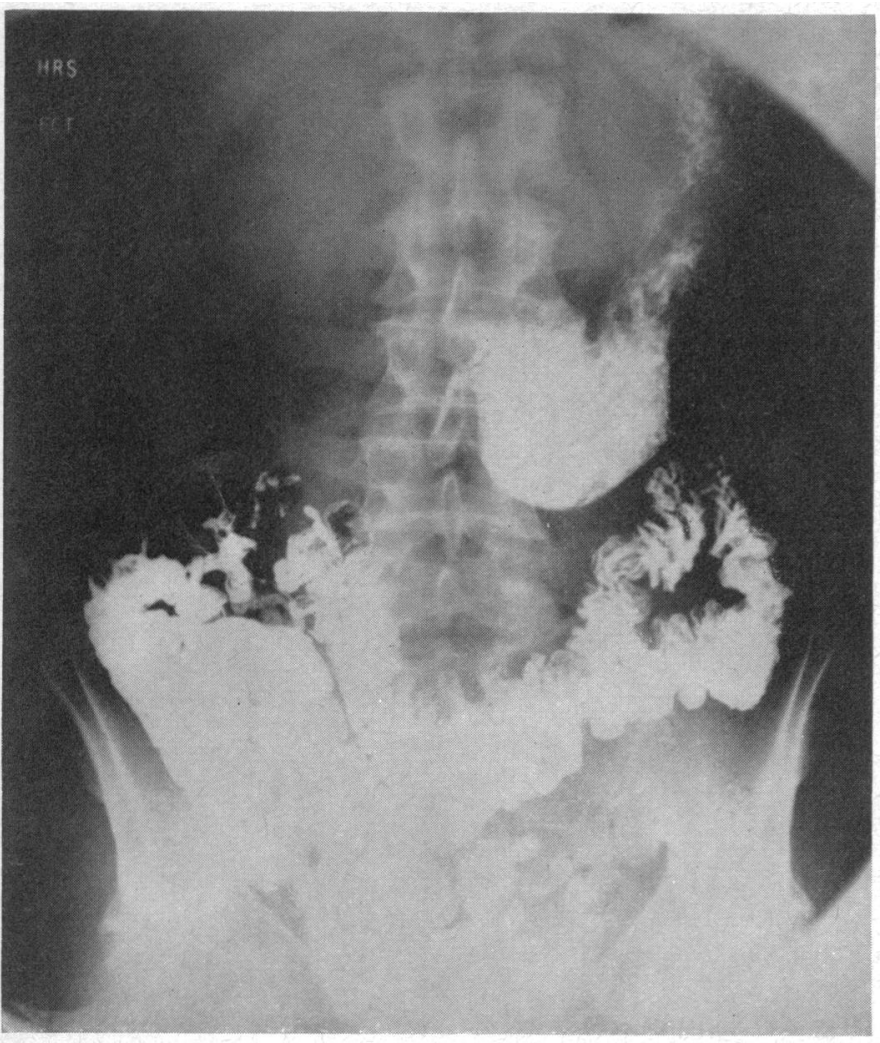

FIG. 6.-Gastric retention seven months after selective vagotomy without drainage (special meal at nine hours).

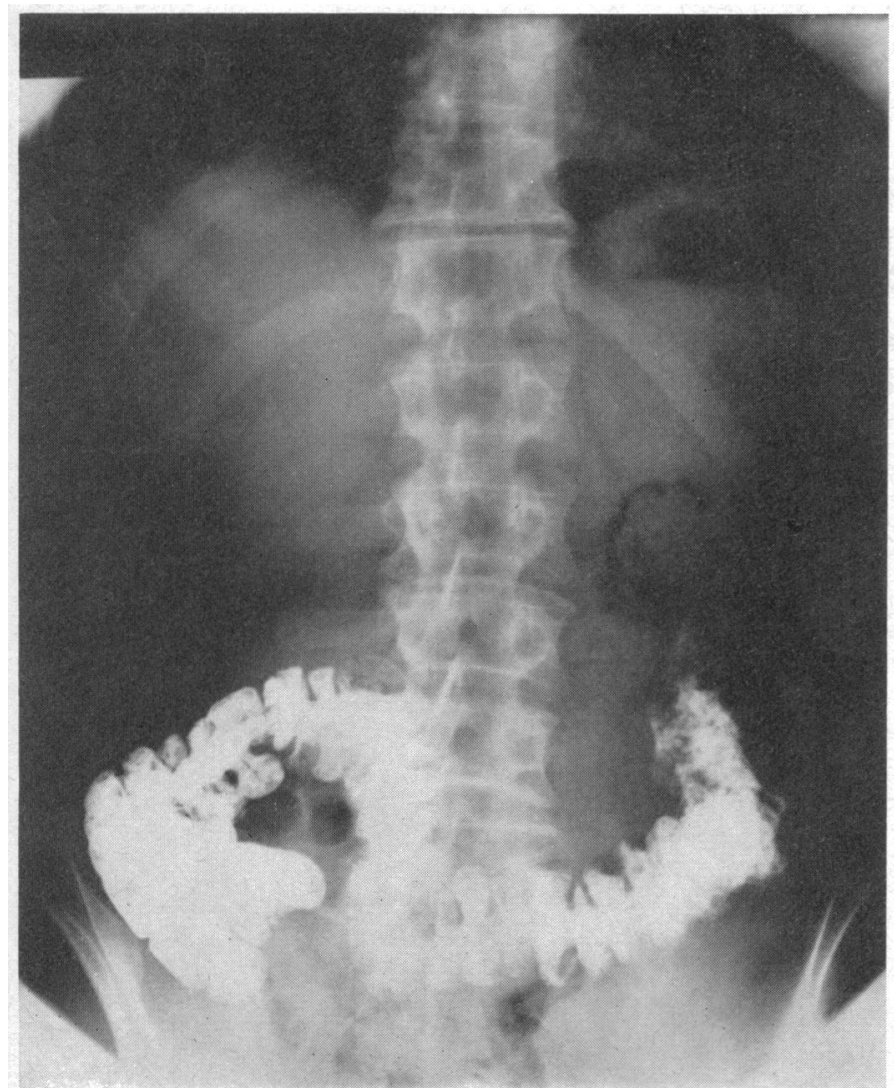

FIG. 7.-Stomach empty in same patient at 19 months after operation.

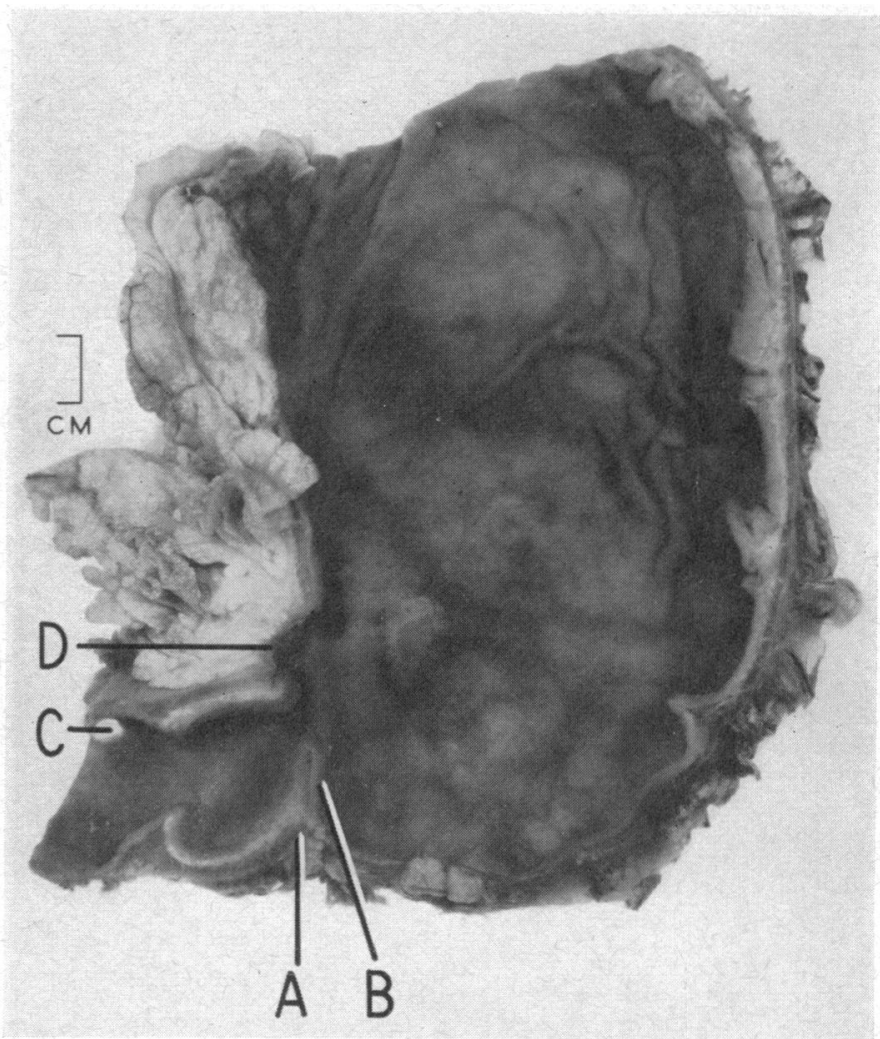

Fig. 5.- Mucosal stenosis in gastric ulcer. $A=$ Slight muscular stenosis. $B=$ Severe mucosal stenosis. $C=$ Perforated duodenal ulcer. $D=$ Lesser curve gastric ulcer.

N. A. SIMMONS: POTENTIATION OF COLISTIN

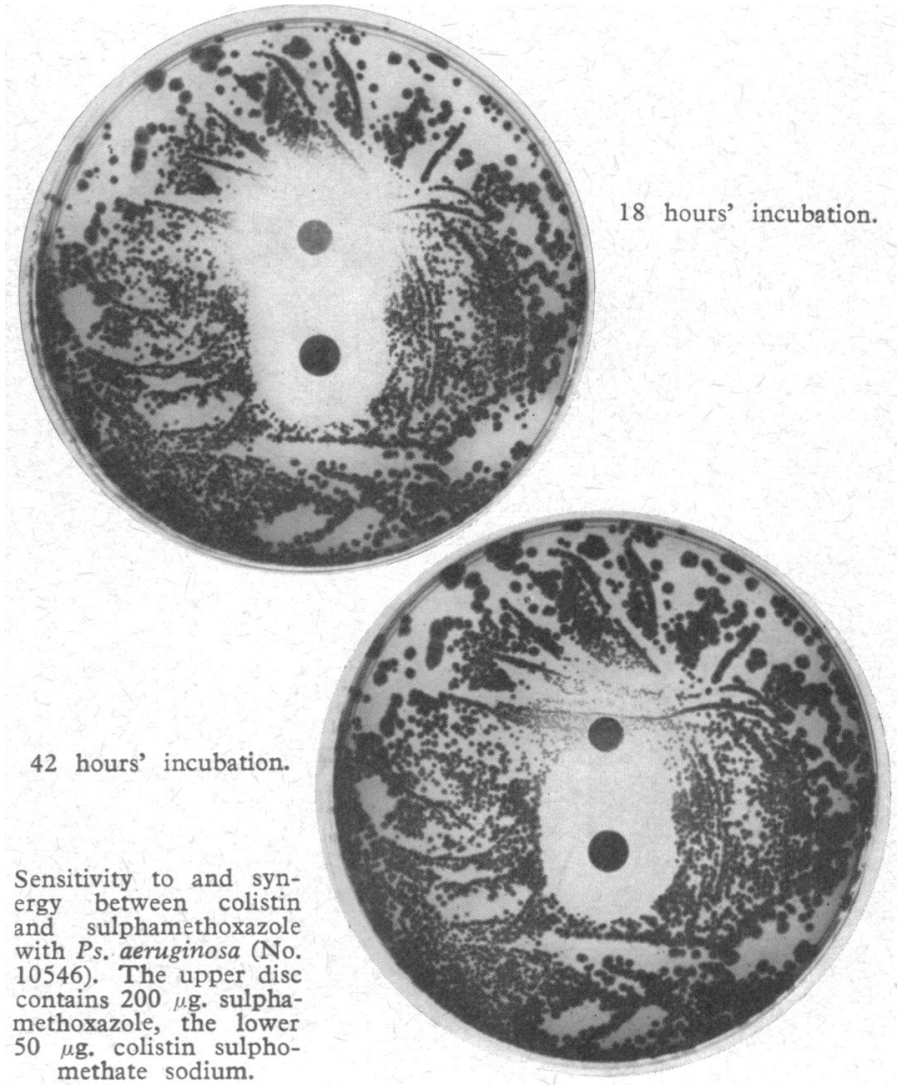


eliminates the complication of dumping, for which there is no very satisfactory treatment. Before pyloroplasty can be omitted, however, two conditions should be fulfilled. There should be very little or preferably no visible organic narrowing of the duodenum as seen at operation, and the vagotomy should be selective. It may be important to avoid damage to the lower fibres of the hepatic plexus during the anterior selective vagotomy. It is in the lowest part of this plexus that the hepatic nerves are most concentrated, forming a clearly visible structure formerly referred to erroneously as the hepatic branch of the anterior vagus (Fig. III). It is also desirable to avoid incomplete gastric nerve section; this is best done with the help of a test at the time of operation.

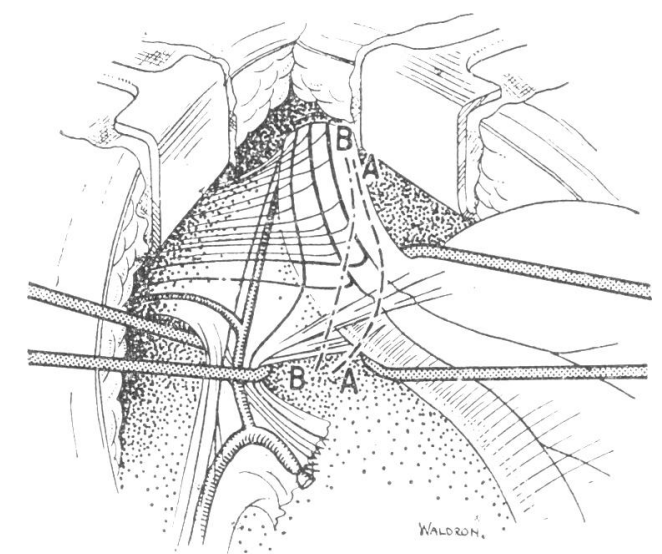

FIG. III-Line of section in anterior selective vagotomy. $\mathrm{AA}=$ Correct line of section. $\mathrm{BB}=$ Incorrect line of section.

Some of us believe that vagotomy and pyloroplasty can, and indeed should, be used in the treatment of benign gastric ulcer, no matter where the lesion may be situated in the stomach. We must now study the place of selective vagotomy without drainage in its treatment. Again it would seem logical to use the operation without drainage for gastric ulceration when there is no organic pyloric ring or duodenal stenosis. Patients with long-standing lesser curve gastric ulcer may have organic stenosis at the pylorus or in the duodenum; these will need pyloroplasty. In earlier cases gastric retention may be caused by spasm secondary to pyloric or duodenal disease in the absence of fibrotic organic stenosis. In these patients the pyloroplasty may perhaps be omitted. Our work in this field shows encouraging results.

Since series 1 and 2-without stenosis and with no pyloroplasty-were completed a further 50 patients have been treated without pyloroplasty. Great care has been taken to use pyloroplasty when there was any possibility of organic mucosal stenosis. In all, over 100 patients have been treated without any drainage procedure.

Although in this work we used the preoperative "special" barium meal to assess pyloroduodenal stenosis, more recent observations have shown that even an empty stomach at six hours should not be accepted as evidence that pyloroplasty may be omitted. An empty film at this time may be found in the presence of quite severe organic stenosis. Probably it is wise to omit pyloroplasty only when at operation the duodenum is quite free from narrowing.

If selective vagotomy without drainage should become the accepted operation for duodenal ulcer it would follow that prolonged conservative treatment which allows time for fibrous stenosis to occur must be deprecated. The trend would therefore be towards earlier though not necessarily premature operation, and there would be even more reason for choosing selective rather than truncal vagotomy.

We would like to thank the Dan Mason Research Foundation of the West London Hospital Medical Trust for its continued support.

\section{REFERENCES}

Agostoni, E., Chinnock, J. R., Daly, M. de Burgh, and Murray, J. G. (1957). Fournal of Physiology, 135, 182.

Buckler, K. G. (1967). Gut, 8, 137.

Burge, H. (1968). The Physiology of Gastric Secretion, p. 27. Oslo, Universitetsforlaget.

Franksson, C. (1948). Acta Chirurgica Scandinavica, 96, 409

Franksson, C. (1948). Acta Chirurgic

George, J. D. (1968). Gut, 9, 237. (1964). Archives of Surgery, 88, 932.
Ares, C. Ae la Rosa, C., Woodward,

Stavney, L. S., Kato, T., Griffith, C. A., Nyhus, L. M., and Harkins, H. N. (1963). Fournal of Surgical Research, 3, 390.

Van Yzeren, W. (1901). Zeitschrift für Klinische Medizin, 43, 181

Wastell, C. (1966). British Medical fournal, 1, 1198.

\title{
Potentiation of Inhibitory Activity of Colistin on Pseudomonas aeruginosa by Sulphamethoxazole and Sulphamethizole
}

\author{
N. A. SIMMONS, * M.B., M.C.PATH. \\ with the Technical Assistance of D. J. McGillicudDy, $\dagger$ A.I.S.T. \\ [With Special Plate between Pages 692-693]
}

British Medical fournal, 1969, 3, 693-696

Summary : Potentiation of colistin by sulphamethoxazole $\checkmark$ and sulphamethizole was demonstrated with 19 out of 20 strains of Pseudomonas aeruginosa. This enhancement was bactericidal as well as bacteriostatic. Synergy between trimethoprim and sulphamethoxazole was also demonstrated with four strains of Ps. aeruginosa, but even when the two drugs were combined high concentrations of trimethoprim were still required to produce a bactericidal effect. Combinations of sulphamethoxazole and gentamicin appeared to be synergistic when the bacteriostatic effect was measured, but the combined bactericidal effect was indifference. The bactericidal and bacteriostatic effect of combinations of carbenicillin with sulphamethoxazole was also indifference.

\section{Introduction}

In an investigation of urinary tract infection eight strains of Pseudomonas aeruginosa were isolated and were found to be moderately sensitive to sulphamethizole (Urolucosil). Subsequently most were shown to be more sensitive to sulphamethoxazole (Gantanol). Though inhibition of the growth of these bacteria by the two sulphonamides was shown, in normal circumstances they are only bacteriostatic, and pseudomonas infections are extremely difficult to eradicate. Consequently the inhibitory effect of the sulphonamides alone was considered

* Consultant Pathologist, Chase Farm Hospital, Enfield, Middlesex. + Research Technician, supported by grants from Lederle Laboratories and the North-east Metropolitan Regional Hospital Board. 
to be of little therapeutic value, and therefore investigations were carried out to determine the in-vitro effect on four of the organisms of combinations of sulphamethoxazole with each of three antibiotics that are commonly used in the treatment of pseudomonas infections-colistin, gentamicin, and carbenicillin. Combinations of the sulphonamides and trimethoprim are known to be synergistic (Darrell, Garrod, and Waterworth, 1968), and though most strains of Ps. aeruginosa are resistant to trimethoprim the effect of combinations of it with sulphamethoxazole on the four organisms was also investigated.

When the combination of sulphamethoxazole and colistin was found to be synergistic with all four organisms its effect on another 16 strains of Ps. aeruginosa was studied, and investigations were carried out on all 20 organisms to determine whether combinations of colistin and the other sulphonamide, sulphamethizole, produced the same effect. The results of these investigations are presented in this paper.

\section{Organisms}

\section{Materials and Methods}

Twenty strains of Ps. aeruginosa were examined-eight from Chase Farm Hospital, three from St. Ann's Hospital, Tottenham, and nine from the Central Public Health Laboratory, Colindale. Their serological and phage type are shown in Table I. Three of the strains isolated in Chase Farm Hospital (Nos. 7966, 10301, and 10546) could not be distinguished from each other by serological or phage-typing, and two other strains from the same centre (Nos. 46 and 10835) and two from St. Ann's Hospital (Nos. 13457 and 50426) also resembled each other as regards their typing pattern. Other characteristics of the organisms within each group were, however, different-for example, their pigment production and their degree of sensitivity to colistin and sulphonamides. The nine strains from the Central Public Health Laboratory were selected because they were of a serological or phage type not represented by the other 11 strains.

TABLE I.-Characteristics of Organisms Studied

\begin{tabular}{|c|c|c|c|c|}
\hline \multirow{2}{*}{$\begin{array}{l}\text { Organism } \\
\text { No. }\end{array}$} & \multicolumn{2}{|c|}{ Origin } & \multirow{2}{*}{$\begin{array}{l}\text { Serological } \\
\text { Patternt }\end{array}$} & \multirow{2}{*}{$\begin{array}{l}\text { Phage Typet R.T.D. } \\
\text { (R.T.D. } \times 100 \text { in } \\
\text { Parentheses) }\end{array}$} \\
\hline & Centre* & Site & & \\
\hline 46 & C.F.H. & Urine & 11 & $119 \mathrm{X} / \mathrm{M} 6$ \\
\hline 7966 & C.F.H. & Urine & N.T. & $21 / 31 / 68$ \\
\hline 10301 & C.F.H. & Urine & N.T. & $21 / 31 / 68$ \\
\hline 10546 & C.F.H. & Urine & N.T. & $21 / 31 / 68 / 109 / \mathrm{Col} .21$ \\
\hline $\begin{array}{l}10690 \\
10832\end{array}$ & $\begin{array}{l}\text { C.F.H. } \\
\text { C.F.H. }\end{array}$ & $\begin{array}{l}\text { Urine } \\
\text { Urine }\end{array}$ & $\stackrel{6}{5}$ & $\underset{44}{7 / 44 / 68 / \mathrm{F} 8 / 109 / 352 / 1214 / \mathrm{M} 4}$ \\
\hline 10834 & C.F.H. & Urine & 6 & $31 / 68$ \\
\hline 10835 & C.F.H. & Urine & 11 & N.T. \\
\hline 13457 & St.A. & Varicose ulcer & 11 & N.T. \\
\hline 50426 & St.A. & Varicose ulcer & 11 & M6 \\
\hline $\begin{array}{r}49344 \\
968\end{array}$ & $\begin{array}{l}\text { St.A. } \\
\text { P.H.L.S. }\end{array}$ & $\begin{array}{l}\text { Varicose ulcer } \\
\text { Suction }\end{array}$ & 6 & $7 / 68 / 119 \mathrm{X} / \mathrm{M} 4 / \mathrm{Col} .11$ \\
\hline & & machine & 1 & $119 \mathrm{X}$ \\
\hline $\begin{array}{l}779 \\
277 \\
979\end{array}$ & $\begin{array}{l}\text { P.H.L.S. } \\
\text { P.H.L.S. } \\
\text { P.H.L.S. }\end{array}$ & $\begin{array}{l}\text { Sputum } \\
\text { Stool } \\
\text { Tracheostomy }\end{array}$ & $2 \mathrm{~A}$ & $\begin{array}{l}21 / 68 / 1214 / \mathrm{Col} .21 \\
(44 / 1214)\end{array}$ \\
\hline $\begin{array}{r}694 \\
1027 \\
980\end{array}$ & $\begin{array}{l}\text { P.H.L.S. } \\
\text { P.H.L.S. } \\
\text { P.H.L.S. }\end{array}$ & $\begin{array}{l}\text { wound } \\
\text { Sputum } \\
\text { Stool } \\
\text { Tracheostomy }\end{array}$ & $\begin{array}{l}3 \\
8 \\
9\end{array}$ & $\begin{array}{l}7 / 21 / 24 / 68 / 119 \times / C o l .11 /+ \\
7 / 68+ \\
44 / 109 / 1214 / C o l .11 /+\end{array}$ \\
\hline $\begin{array}{r}382 \\
1038\end{array}$ & $\begin{array}{l}\text { P.H.L.S. } \\
\text { P.H.L.S. }\end{array}$ & $\begin{array}{l}\text { wound } \\
\text { Stool } \\
\text { Urine }\end{array}$ & $\begin{array}{r}10 \\
13 \\
4\end{array}$ & $\begin{array}{l}(1214 / \mathrm{M} 6) \\
7 / 68 \\
119 \mathrm{X} / \mathrm{Col} .11\end{array}$ \\
\hline
\end{tabular}

* C.F.H. = Chase Farm Hospital. P.H.L.S. = Central Public Health Laboratory St.A. $=$ St. Ann's Hospital.
+ N.T.
Not typable.

\section{Preliminary Investigation}

A preliminary investigation was carried out to determine the antibacterial effect of combining sulphamethoxazole with colistin, trimethoprim, gentamicin, and carbenicillin. In this study the effect of combining sulphamethoxazole with each of the other compounds was determined by the chessboard technique ; only 4 of the 20 organisms were investigated (Nos. 46, 10690,10546 , and 10832). To test each combination with each organism 144 tubes were used and arranged in 12 rows of 12. A series of combinations of different concentrations of the two drugs under test was prepared. From the back row to the front doubling dilutions of sulphamethoxazole in Oxoid sensitivity test broth were made, beginning with a concentration of $100 \mu \mathrm{g} . / \mathrm{ml}$. From left to right in each row doubling dilutions of the other agent under test were made, the initial concentration being $100 \mu \mathrm{g} . / \mathrm{ml}$. for colistin sulphomethate sodium and trimethoprim, $200 \mu \mathrm{g} . / \mathrm{ml}$. for carbenicillin, and $12.5 \mu \mathrm{g} . / \mathrm{ml}$. for gentamicin base. The front row of tubes contained no sulphamethoxazole and the last tube in each row contained none of the other agent. Each tube was inoculated with $0.02 \mathrm{ml}$. of a 1 in 10,000 dilution of an overnight sensitivity broth culture of the organism under test, an inoculum of between 5,000 and 10,000 organisms, incubated at $37^{\circ} \mathrm{C}$. for 18 hours and examined for visible growth. A loopful of broth from each tube was then subcultured on to Oxoid diagnostic sensitivity test agar which was incubated at $37^{\circ} \mathrm{C}$. for 18 hours to determine whether inhibition was due to a bacteriostatic or bactericidal effect.

The bacteriostatic and bactericidal effects of a combination were designated as "antagonism" when the combined effect was less than the better of the drugs alone, "indifference" when each drug behaved as if the other was not present, "partial synergy" when the combination was better but less than four times as good as either drug alone, and "synergy" when the combination was at least four times as effective as the more effective member (Bulger and Kirby, 1963).

\section{Further Investigation}

As a consequence of the results of the preliminary investigation it was decided to examine further the effect of combinations of colistin and sulphamethoxazole, and to see if combinations of colistin and the other sulphonamide, sulphamethizole, produced the same effect. Thus, in these later investigations the effect of combining colistin with each of the two sulphonamides was determined against all 20 strains of Ps. aeruginosa. As the chessboard technique used in the earlier studies was laborious and time-consuming a simpler method was employed.

$0.1 \mathrm{ml}$. of a 1 in 10,000 dilution of an 18-hour sensitivity broth culture of each test organism was spread over the surface of two Petri dishes of $9-\mathrm{cm}$. diameter containing Oxoid diagnostic sensitivity test agar. On one a filter-paper disc containing $50 \mu \mathrm{g}$. of colistin sulphomethate sodium was placed with its margin $1.5 \mathrm{~cm}$. from the margin of a disc containing $200 \mu \mathrm{g}$. of sulphamethoxazole, and on the other a colistin disc was placed $1 \mathrm{~cm}$. from a disc containing $200 \mu \mathrm{g}$. of sulphamethizole. The plates were incubated at $37^{\circ} \mathrm{C}$. for 18 hours and examined, and then colistin-sulphamethoxazole plates were reincubated at $37^{\circ} \mathrm{C}$. and the colistin-sulphamethizole plates left at room temperature for a further 24 hours. The sensitivity of organisms to each drug acting alone was read after the first 18 hours, but the combined effect could not be determined at this time as zones of inhibition around the discs merged into each other. Twenty-four hours later, however, surviving organisms around the sulphonamide discs had grown, and eccentricity of the zones around the colistin discs, indicating potentiation of this antibiotic by the sulphonamides, was clearly demonstrable (see Fig.). One strain of Pseudomonas (No. 694) was slow to grow and incubation times for this organism were doubled.

This method showed the presence of synergy and whether organisms were sensitive to individual drugs, but gave no precise measure of the degree of sensitivity. Therefore the minimal inhibitory concentrations (M.I.C.s) of sulphamethoxazole, sulphamethizole, and colistin acting alone were determined for all 20 organisms by a tube dilution technique. Stock solutions of sulphamethoxazole and sulphamethizole containing $10,000 \mu \mathrm{g} . / \mathrm{ml}$. were prepared by dissolving $0.5 \mathrm{~g}$. of pure 
TABLE II.-Minimal Inhibitory Concentrations (M.I.C.) and Minimal Bactericidal Concentrations (M.B.C.) in $\mu$ g./ml. of Sulphamethoxazole, Colistin, Trimethoprim, and Gentamicin, Alone and in Combination for Four Strains of Ps. aeruginosa

\begin{tabular}{|c|c|c|c|c|c|c|c|c|c|c|c|c|c|c|}
\hline \multirow{3}{*}{$\begin{array}{l}\text { Organism } \\
\text { No. }\end{array}$} & \multicolumn{8}{|c|}{ Drugs Acting Alone } & \multicolumn{6}{|c|}{ Drug Combinations* } \\
\hline & \multicolumn{2}{|c|}{ Sulphamethoxazole } & \multicolumn{2}{|c|}{$\begin{array}{c}\text { Colistin } \\
\text { Sulphomethate }\end{array}$} & \multicolumn{2}{|c|}{ Trimethoprim } & \multicolumn{2}{|c|}{ Gentamicin } & \multicolumn{2}{|c|}{$\begin{array}{c}\text { Sulphamethoxazole/ } \\
\text { Colistin }\end{array}$} & \multicolumn{2}{|c|}{$\begin{array}{c}\text { Sulphamethoxazole/ } \\
\text { Trimethoprim }\end{array}$} & \multicolumn{2}{|c|}{$\begin{array}{c}\text { Sulphamethoxazole/ } \\
\text { Gentamicin }\end{array}$} \\
\hline & M.I.C. & M.B.C. & M.I.C. & M.B.C. & M.I.C. & M.B.C. & M.I.C. & M.B.C. & M.I.C. & M.B.C. & M.I.C. & M.B.C. & M.I.C. & M.B.C. \\
\hline 46 & $6 \cdot 25$ & $>100$ & 1.6 & $12 \cdot 5$ & 25 & $>100$ & $0 \cdot 1$ & $0 \cdot 2$ & 53 & 53 & $S 0.8$ & & S 3. & $S>100$ \\
\hline 10546 & $12 \cdot 5$ & $>100$ & 0.4 & $6 \cdot 25$ & 50 & $>100$ & $0 \cdot 1$ & $0 \cdot 1$ & 56.25 & S 6.25 & 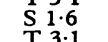 & S $6 \cdot 25$ & 53. & $S>100$ \\
\hline 10690 & $6 \cdot 25$ & $>100$ & 0.8 & $3 \cdot 1$ & 50 & $>100$ & 0.04 & 0.1 & $\begin{array}{l}5 \\
S\end{array} 3.1$ & $\begin{array}{l}1.0 \\
S 12.5\end{array}$ & $\begin{array}{l}1 \\
\text { S } 3.1 \\
T\end{array}$ & S 12.5 & $\begin{array}{l}S 1.6 \\
G 1.62\end{array}$ & $S>100$ \\
\hline 10832 & $6 \cdot 25$ & $>100$ & $3 \cdot 1$ & 25 & 25 & $>100$ & 0.04 & $0 \cdot 1$ & $\begin{array}{l}S 1.6 \\
\mathrm{C} 0.4\end{array}$ & $\begin{array}{l}\text { S } 12.5 \\
\text { C } 3.1\end{array}$ & $\begin{array}{l}1.10 \\
\mathrm{~T} 0.8 \\
\end{array}$ & $\begin{array}{l}\mathrm{S} \\
\mathrm{S} \\
\mathrm{T} \\
12.5\end{array}$ & $\begin{array}{l}S 3.1 \\
\text { G } 0.01\end{array}$ & $\begin{array}{l}S>100 \\
G>0.1\end{array}$ \\
\hline
\end{tabular}

* $\mathrm{S}=$ Sulphamethoxazole. $\quad \mathrm{C}=$ Colistin sulphomethate. $\mathrm{T}=$ Trimethoprim. $\mathrm{G}=$ Gentamicin

powder in $2.5 \mathrm{ml}$. of $\mathrm{N} \mathrm{NaOH}$ and making this up to $50 \mathrm{ml}$. with distilled water. These solutions were sterilized by passing them through a Millipore filter and stored at $-20^{\circ} \mathrm{C}$. Working solutions containing $1,000 \mu \mathrm{g} . / \mathrm{ml}$. in sensitivity test broth were prepared from stock solutions. They were stored at $4^{\circ} \mathrm{C}$, , remaining stable for at least 14 days. From the working solutions tubes containing $1 \mathrm{ml}$. of sensitivity test broth in which the sulphonamide was present in the concentrations 200 , $100,50,25$, and $12.5 \mu \mathrm{g} . / \mathrm{ml}$. were prepared, and each was inoculated with $0.02 \mathrm{ml}$. of a 1 in 10,000 dilution in distilled water of an overnight sensitivity broth culture and incubated at $37^{\circ}$ C. for 18 hours. The M.I.C. was taken from the tube containing the lowest concentration of sulphonamide that clearly inhibited bacterial growth.

The minimal bactericidal concentration (M.B.C.) was determined by subculturing a loopful of growth from tubes in which there was no visible growth on to diagnostic sensitivity test agar, which was incubated for 24 hours. A bactericidal effect was demonstrated by a sterile subculture. Incubation times for organism No. 694 were doubled. For colistin the procedure was similar to that used for the sulphonamides, but colistin solutions were made up in distilled water, and, in the test, tubes containing sensitivity test broth in which colistin sulphomethate sodium was present in the concentrations $12.5,6.25$, $3 \cdot 1,1 \cdot 6,0.8$, and $0.4 \mu \mathrm{g} . / \mathrm{ml}$. were used.

\section{Results}

\section{Preliminary Investigation}

All four strains of Ps. aeruginosa behaved similarly when subjected to combinations of sulphamethoxazole and one of the other agents.

Combinations with colistin were synergistic, and this was apparent when both bacteriostatic and bactericidal effects were determined. Sulphamethoxazole alone was only bacteriostatic, but relatively low concentrations of it greatly enhanced the bactericidal effect of colistin (Table II).

Combinations of sulphamethoxazole and trimethoprim produced a synergistic bacteriostatic effect, and though trimethoprim alone, like sulphamethoxazole, was not bactericidal combinations of the two drugs were, but only when relatively high concentrations of trimethoprim were present (Table II).

Combinations of gentamicin and sulphamethoxazole appeared to be synergistic or partially synergistic when the bacteriostatic effect was measured, but the reduction of the M.I.C. of gentamicin was never more than fourfold, and when the combined bactericidal effect was determined each drug behaved as if the other were not present, the M.B.C. of gentamicin was unaltered by sulphamethoxazole, and therefore the combined bactericidal effect was indifference (Table II).

When the effect of combinations of carbenicillin and sulphamethoxazole was studied each drug behaved as if the other were not present and the M.I.C. and M.B.C. of each drug were unaltered in the presence of the other; the combined effect was therefore indifference. The M.I.C.s and M.B.C.s of carbenicillin are shown in Table III.

TABLe III.-M.I.C. and M.B.C.* ( $\mu \mathrm{g} . / \mathrm{ml}$.$) of Carbenicillin for Four$ Strains of Ps. aeruginosa

\begin{tabular}{c|c|c}
\hline Organism No. & M.I.C. & M.B.C. \\
\hline 46 & $6 \cdot 25$ & $12 \cdot 5$ \\
10546 & 50 & 100 \\
10690 & 25 & 50 \\
10832 & 25 & 25 \\
\hline
\end{tabular}

* These concentrations were unaffected by sulphamethoxazole.

\section{Further Investigation}

With 19 of the 20 organisms tested synergy was observed both between colistin and sulphamethoxazole and between colistin and sulphamethizole. The M.I.C.s and M.B.C.s of the three agents acting alone are shown in Table IV. Sulphamethoxazole was more active than sulphamethizole. For only one organism (No. 968) was the M.I.C. of both sulphonamides greater than $200 \mu \mathrm{g} . / \mathrm{ml}$. With this strain after 18 hours' incubation there was a zone of inhibition around the colistin disc, but no zone around the sulphonamide discs, and it was the only strain with which synergy between colistin and the sulphonamides was not seen.

TABLE IV.-M.I.C. and M.B.C. $(\mu g . / m l$.$) of Sulphamethoxazole, Sulpha-$ methizole, and Colistin for 20 Strains of Ps. aeruginosa

\begin{tabular}{|c|c|c|c|c|c|c|}
\hline & \multicolumn{6}{|c|}{ M.I.C. } \\
\hline & $\leqslant 12 \cdot 5$ & 25 & 50 & 100 & 200 & $>200$ \\
\hline \multirow{4}{*}{ 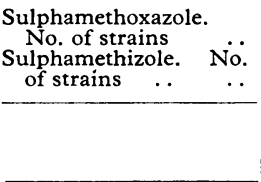 } & 18 & 0 & 1 & 0 & 0 & 1 \\
\hline & 4 & 4 & 4 & 6 & 1 & \\
\hline & \multicolumn{6}{|c|}{ M.B.C. } \\
\hline & $\leqslant 12 \cdot 5$ & 25 & 50 & 100 & 200 & $>200$ \\
\hline \multirow{5}{*}{$\begin{array}{l}\text { Sulphamethoxazole. } \\
\text { No. of strains } \\
\text { Sulphamethizole. } \\
\text { of strains . . }\end{array}$} & 0 & 0 & 0 & 3 & 2 & 15 \\
\hline & 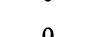 & 0 & 0 & & & \\
\hline & 0 & 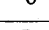 & 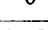 & 0 & 0 & \\
\hline & \multicolumn{6}{|c|}{ M.I.C. Colistin Sulphomethate Sodium } \\
\hline & $\leqslant 0 \cdot 8$ & $1 \cdot 6$ & $3 \cdot 1$ & $6 \cdot 25$ & $12 \cdot 5$ & $>12 \cdot 5$ \\
\hline \multirow[t]{3}{*}{ No. of strains .. } & 16 & 1 & 2 & 0 & 1 & 0 \\
\hline & \multicolumn{6}{|c|}{ M.B.C. Colistin Sulphomethate Sodium } \\
\hline & $\leqslant 0 \cdot 8$ & 1.6 & $3 \cdot 1$ & $6 \cdot 25$ & $12 \cdot 5$ & $>12.5$ \\
\hline No. of strains .. & 6 & 3 & 3 & 5 & 1 & 2 \\
\hline
\end{tabular}

\section{Discussion}

Combinations of colistin and the sulphonamides have previously been shown to be synergistic, but most of the observations have been made with Proteus species (Russell, 1963). Truant and Penn (1964) investigated the effect of combinations of colistin sulphate with sulphafurazole and with sulphacetamide on 11 strains of Pseudomonas. The 
sulphonamides they tested were less active when used alone against their organisms-for all of which the M.I.C.s were more than $100 \mu \mathrm{g} . / \mathrm{ml}$. - than were the sulphonamides we used against our organisms. Nevertheless, they demonstrated enhanced inhibition of 5 of their 11 strains when sulphafurazole was used in combination with colistin. When sulphacetamidecolistin combinations were used enhancement was seen with only one strain. We used two active sulphonamides, sulphamethoxazole and sulphamethizole, and each in combination with colistin greatly enhanced its inhibitory effect on 19 of our 20 strains of Pseudomonas. With all four strains which were more fully investigated we clearly showed that the enhancement was not only bacteriostatic but also bactericidal. The one strain with which we failed to demonstrate potentiation was the only one which was resistant to high concentrations of each sulphonamide acting alone. With most of the other strains sulphamethoxazole by itself was more active than sulphamethizole.

Most of the antibiotics used in the treatment of pseudomonas infections are expensive, are of low activity, or have toxic sideeffects, and the infections which frequently occur in patients who have previously been given antibacterial treatment may be extremeiy difficult to eradicate. Under these circumstances the potentiation of colistin by sulphamethoxazole or sulphamethizole could prove to be a valuable therapeutic aid, and a trial of combined treatment of infections caused by strains of Pseudomonas sensitive to these sulphonamides would certainly seem to be justifiable. It must be emphasized here that the conditions of in-vitro tests of sensitivity to the sulphonamides and the potentiation of colistin by them must be rigidly controlled by using methods such as those described in this paper, for variations in such things as inoculum size or the type of medium can easily give rise to erroneous results.

Most strains of Ps. aeruginosa are resistant to trimethoprim, but pseudomonal urinary tract infections have been successfully treated with combinations of it with sulphamethoxazole (Grüneberg and Kolbe, 1969). We were able to demonstrate synergy with this combination on four strains, but high concentrations of trimethoprim were still required to produce a bactericidal effect.

We wish to thank Dr. M. T. Parker for the serological and phage-typing of all the organisms and for supplying those from the Central Public Health Laboratory, Colindale, and Dr. E. G. Dowsett for supplying the organisms from St. Ann's Hospital, London N.15.

\section{REFERENCES}

Bulger, R. J., and Kirby, W. M. M. (1963). American fournal of the Medical Sciences, 246, 717.

Darrell, J. H., Garrod, L. P., and Waterworth, P. M. (1968). Fournal of Clinical Pathology, 21, 202.

Grüneberg, R. N., and Kolbe, R. (1969). British Medical fournal, 1, 545. Russell, F. E. (1963). fournal of Clinical Pathology, 16, 362.

Truant, J. P., and Penn, W. P. (1964). In The 3rd International Congress of Chemotherapy, vol. 1, edited by H. P. Kuemmerle and P. Prez:osi, p. 284. Stuttgart, Thieme.

\section{Preliminary Communications}

\section{Reduction of Lumbar Disc Prolapse by Manipulation}

[With Special Plate between Pages 692-693]

\author{
British Medical Fournal, 1969, 3, 696-697
}

Summ

mmary : In two patients with symptoms and signs characteristic of a mechanical lumbar spine disorder epidurography showed the presence of small disc prolapses. Treatment by manipulation relieved the symptoms of lumbago, and repeat epidurography showed that the prolapses were reduced in size. Reduction of disc prolapse by manipulation has not before been objectively demonstrated.

\section{INTRODUCTION}

Manipulation of the lumbar spine has been used as an empirical treatment of low backache since antiquity. The persistence and popularity of this type of treatment was based on the clinical impression that it is beneficial. By contrast, evidence that protrusion of an intervertebral disc could be responsible for low backache is comparatively recent. The first report of disc herniation was the post-mortem description by Virchow (1857), and the first clinical descriptions were those of Goldthwait (1911) and Middleton and Teacher (1911). The wider clinical importance of disc protrusions was emphasized by Mixter and Barr (1934), who reported patients with protrusions at cervical, dorsal, and lumbar levels. Most of their patients had a neurological lesion, and histology of the surgically removed lesions showed them to be disc protrusions rather than fibrous tumours.
The evidence that lesser degrees of the syndrome of lumbago and sciatica are due to lesser disc protrusions is circumstantial. The frequent accompaniment of acute onset low back pain by spinal deformity suggests a mechanical factor, and the accompanying abnormality of straight-leg raise or femoral stretch test suggests that the lesion impinges on the spinal dura mater or the dural nerve sheaths. That this clinical picture may advance to sciatica with neurological deficit, and be cured by surgical removal of a disc prolapse, indicates a common and sometimes progressive morbidity-a lumbar disc prolapse. Further evidence that the basic pathological lesion is closely related to the epidural part of the spinal canal is provided by the observation that epidural injections of local anaesthetic relieve the symptoms (Evans, 1930).

The controversy surrounding the mechanism of lumbago and its relief by manipulation led us to select patients thought likely to benefit from lumbar manipulation. Clinical features were correlated with those shown on radiographs taken after epidural injections of contrast medium (epidurograms).

\section{Methods}

Patients were considered for this study if they had features thought by Cyriax (1962) to suggest a disc protrusion likely to be helped by manipulation. All patients had lumbago of rapid onset, which was of less than one week's duration and did not radiate below the knee. Limitation of lumbar movement and signs of dural irritation (abnormalities of straightleg raise and femoral stretch tests) were recorded. Patients with a neurological deficit were excluded.

Standard lateral radiographs, taken with the patient prone, were used throughout. Urografin $50 \%, 10-20 \mathrm{ml}$., was injected 